\title{
Occurrence of hemolytic anemia in patients with GBS treated with high-dose IVIg OPEN
}

Thy P. Nguyen, MD Suur Biliciler, MD Amer Wahed, MD Kazim Sheikh, MD

Correspondence to Dr. Nguyen: thy.p.nguyen@uth.tmc.edu

\section{ABSTRACT}

Objective: We describe an underrecognized side effect of high-dose IV immunoglobulin (IVIg), hemolytic anemia.

Background: There are no established guidelines on treating patients with Guillain-Barré syndrome (GBS) who relapse or do not improve after a standard course of treatment (IVIg or plasma exchange). Some centers will opt for a second course of the initial treatment. There is an ongoing trial of a second course of IVIg in patients with severe GBS.

Methods: We retrospectively reviewed 4 patients with severe GBS who received high-dose IVIg. One patient inadvertently received a high dose of IVIg for Miller Fisher syndrome. All patients received a total of at least 2 courses of the standard dose of IVIg (total $>4 \mathrm{~g} / \mathrm{kg}$ ). We review their clinical course and side effects.

Results: All patients with non-O blood types developed clinically significant hemolytic anemia requiring blood transfusion.

Conclusion: Hemolytic anemia may limit doses of IVIg for treatment of severe GBS in patients with non-O blood types. Neurol Neuroimmunol Neuroinflammation 2014;1:e50; doi: 10.1212/ NXI.0000000000000050

\section{GLOSSARY}

GBS = Guillain-Barré syndrome; HA = hemolytic anemia; IVIg = IV immunoglobulin; MFS = Miller Fisher syndrome.

Guillain-Barré syndrome (GBS) is the most common cause of acute flaccid neuromuscular paralysis, resulting in significant morbidity and cost. ${ }^{1}$ There is a proposed model to identify patients with poor prognosis. ${ }^{1}$ However, treatment options beyond IV immunoglobulin (IVIg) and plasma exchange are limited. ${ }^{2}$ An ongoing trial is evaluating a second course of IVIg for severe GBS. ${ }^{1}$ This trial has prompted treating neurologists to consider an additional course of IVIg if patients do not respond initially. We alert neurologists to significant hemolytic anemia (HA) in patients with non-O blood types treated with high-dose IVIg within a short time interval.

METHODS This is a retrospective case series. We review 4 patients with severe GBS and one patient with Miller Fisher syndrome (MFS) admitted to our institution from 2012 to 2013. All patients received very high-dose IVIg (total dose of at least $4 \mathrm{~g} / \mathrm{kg}$, equivalent to 2 standard treatment courses $[2 \mathrm{~g} / \mathrm{kg}]$ ) administered over fewer than 14 days. All patients with GBS did not respond initially, prompting a second course of treatment (table). The patient with MFS received a high dose inadvertently. We gathered data regarding the incidence of HA in these patients. As this was a retrospective review of a small case series, institutional review board approval was not required.

RESULTS All of the patients with non-O blood types (3/5) treated with very high-dose IVIg developed clinically significant anemia requiring blood transfusion. When tested ( $2 / 3$ cases), there was clear evidence of hemolysis (positive direct antiglobulin test, low haptoglobin, high lactate dehydrogenase/bilirubin). In addition, there were no other medical comorbidities or medications commonly implicated in causing autoimmune hemolytic anemia (table). Patient 4 developed hematuria prior to discharge with normal

From the Departments of Neurology (T.P.N., S.B., K.S.) and Pathology (A.W.), University of Texas Health Science Center at Houston, TX. Go to Neurology.org/nn for full disclosures. Funding information and disclosures deemed relevant by the authors, if any, are provided at the end of the article. The Article Processing Charge was paid by the authors.

This is an open access article distributed under the terms of the Creative Commons Attribution-Noncommercial No Derivative 3.0 License, which permits downloading and sharing the work provided it is properly cited. The work cannot be changed in any way or used commercially. 


\begin{tabular}{|c|c|c|c|c|c|c|c|c|c|}
\hline \multirow{2}{*}{$\begin{array}{l}\text { Table } \\
\text { Patient }\end{array}$} & \multicolumn{9}{|c|}{ Patient characteristics and treatment } \\
\hline & Age, $y$ & Diagnosis & $\begin{array}{l}\text { MRC sum } \\
\text { score }\end{array}$ & $\begin{array}{l}\text { Medical } \\
\text { comorbidities }\end{array}$ & $\begin{array}{l}\text { ABO Rh } \\
\text { type }\end{array}$ & $\begin{array}{l}\text { Symptomatic } \\
\text { anemia }\end{array}$ & $\begin{array}{l}\text { Hemolysis } \\
\text { testing }^{\text {a }}\end{array}$ & $\begin{array}{l}\text { IVlg } \\
\text { dose }\end{array}$ & Dosing regimen \\
\hline 1 & 32 & GBS, AMAN & 16 & None & $A+$ & Yes & Yes & $4 \mathrm{~g} / \mathrm{kg}$ & $400 \mathrm{mg} / \mathrm{kg} /$ day for 10 days \\
\hline 2 & 82 & GBS & 14 & $\begin{array}{l}\text { Melanoma, } \\
\text { bradycardia }\end{array}$ & 0 & No & No & $4 \mathrm{~g} / \mathrm{kg}$ & $400 \mathrm{mg} / \mathrm{kg} /$ day for 10 days \\
\hline 3 & 61 & GBS & 2 & Obesity & $\mathrm{B}+$ & Yes & No & $4 \mathrm{~g} / \mathrm{kg}$ & $400 \mathrm{mg} / \mathrm{kg} /$ day for 10 days \\
\hline 4 & 57 & MFS & 30 & Heart disease & $\mathrm{A}+$ & Yes & Yes & $5 \mathrm{~g} / \mathrm{kg}$ & $1 \mathrm{~g} / \mathrm{kg} /$ day for 5 days \\
\hline 5 & 72 & GBS & 0 & Heart disease & 0 & No & No & $4 \mathrm{~g} / \mathrm{kg}$ & $400 \mathrm{mg} / \mathrm{kg} /$ day for 10 days \\
\hline
\end{tabular}

Abbreviations: AMAN = acute motor axonal neuropathy; GBS = Guillain-Barré syndrome; IVIg = IV immunoglobulin; MFS = Miller Fisher syndrome; MRC = Medical Research Council.

${ }^{a}$ Hemolysis testing indicates the patient's serum was consistent with hemolysis: high lactate dehydrogenase, positive direct antiglobulin test, and low haptoglobin. Note patient 3 was not tested for these parameters.

hemoglobin and returned with massive hemolysis leading to pigmentary nephropathy and requiring hemodialysis. Full neurologic recovery occurred in 2 of the 3 patients who developed HA. Patients with $\mathrm{O}$ blood type did develop anemia, but it was mild and clinically asymptomatic. In addition, the patients with O blood type did not have evidence of hemolysis.

Mechanism. Antibodies to blood group antigens (A and B) found in IVIg due to pooling from donors with $\mathrm{O}$ type blood are proposed as the hemolytic mechanism in many prior observations. ${ }^{3-7}$ The current industry standard antibody titers are $<1: 64$ for anti-A and $<1: 32$ for anti-B. Privigen, a commonly used liquid IVIg formulation, currently has anti-A $<1: 32$ and anti-B $<1: 16$. However, the titers of anti-A and anti-B may vary within lots. Therefore, patients who are given higher doses of IVIg will be exposed to higher levels of anti-A and anti-B antibodies. Although our patients received Privigen, HA has been reported with use of many liquid IVIg formulations. ${ }^{3-7}$

DISCUSSION We propose that risk of IVIg-related $\mathrm{HA}$ is increased with high doses, significant in non-O blood types, and more likely to occur when administered over a short interval (i.e., $<2$ weeks). HA has not been frequently observed in patients receiving maintenance IVIg, likely due to the lower dose, longer time intervals between infusions (typically 3-4 weeks), and 2-3 week half-life of anti-A/B IgG. Although all of our patients had GBS/MFS, HA has been reported in many other conditions treated with high-dose IVIg such as postpolio syndrome, chronic inflammatory demyelinating polyneuropathy, myasthenia gravis, renal transplantation, and Kawasaki disease. $^{3-7}$

The applicability of our findings is limited by a small number of cases, retrospective analysis, and hemolysis testing in only 2 of the 3 patients. However, our findings raise relevant, novel considerations such as a possible maximum tolerated dose of IVIg in a short time frame. In addition, practitioners should exercise caution if considering escalating IVIg dosages to $>2 \mathrm{~g} / \mathrm{kg}$ in $<14$ days. Hemoglobin and creatinine levels should be monitored closely during and after treatment with high-dose IVIg (up to 1-2 weeks) to detect this untoward complication. In the literature, nadir hemoglobin level seemed to occur within 2 weeks of treatment, commonly within 4-5 days. ${ }^{5-7}$ If anemia occurs, testing should include direct antiglobulin test, peripheral blood smear, bilirubin, haptoglobin, lactate dehydrogenase, and reticulocyte count. IVIg lots can be tested for anti-A and anti-B titers. In addition, a crossmatch could be performed with serum and IVIg. Manufacturers should label anti-A and anti-B titers on their product and consider more stringent industry standards. We propose that there is a maximal tolerated dose of IVIg over a 2-week period, which is dependent on patient $\mathrm{ABO}$ blood group and IVIg's anti-A/anti-B titers.

\section{AUTHOR CONTRIBUTIONS}

Dr. Nguyen: study concept, design, acquisition of data, analysis, interpretation. Dr. Biliciler: critical revision of the manuscript for important intellectual content. Dr. Wahed: critical revision of the manuscript for important intellectual content. Dr. Sheikh: critical revision of the manuscript for important intellectual content, study supervision.

\section{STUDY FUNDING}

No targeted funding reported.

\section{DISCLOSURE}

The authors report no disclosures. Go to Neurology.org/nn for full disclosures.

Received June 27, 2014. Accepted in final form October 24, 2014.

\section{REFERENCES}

1. Walgaard C, Lingsma HF, Ruts L, van Doorn PA, Steyerberg EW, Jacobs BC. Early recognition of poor prognosis in Guillain-Barre syndrome. Neurology 2011;76:968-975.

2. Hughes RA, Swan AV, van Doorn PA. Intravenous immunoglobulin for Guillain-Barre syndrome. Cochrane Database Syst Rev 2012;7:CD002063. 
3. Markvardsen LH, Christiansen I, Harbo T, Jakobsen J. Hemolytic anemia following high dose intravenous immunoglobulin in patients with chronic neurological disorders. Eur J Neurol 2014;21:147-152.

4. Wilson JR, Bhoopalam H, Fisher M. Hemolytic anemia associated with intravenous immunoglobulin. Muscle Nerve 1997;20:1142-1145.

5. Kahwaji J, Barker E, Pepkowitz S, et al. Acute hemolysis after high-dose intravenous immunoglobulin therapy in highly HLA sensitized patients. Clin J Am Soc Nephrol 2009;4:1993-1997.

6. Berard R, Whittemore B, Scuccimarri R. Hemolytic anemia following intravenous immunoglobulin therapy in patients treated for Kawasaki disease: a report of 4 cases. Pediatr Rheumatol Online J 2012;10:10.

7. Daw Z, Padmore R, Neurath D, et al. Hemolytic transfusion reactions after administration of intravenous immune (gamma) globulin: a case series analysis. Transfusion 2008;48:1598-1601. 


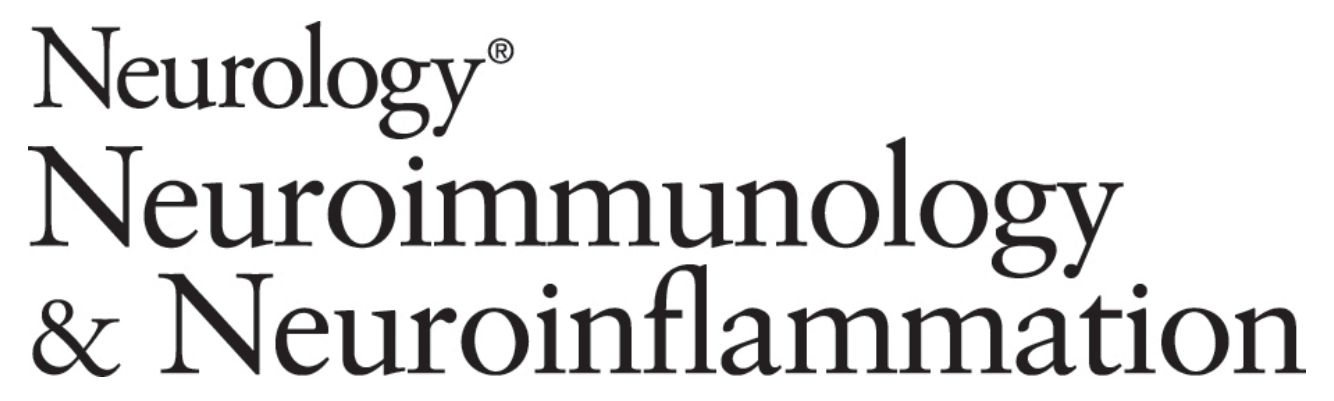

Occurrence of hemolytic anemia in patients with GBS treated with high-dose IVIg Thy P. Nguyen, Suur Biliciler, Amer Wahed, et al. Neurol Neuroimmunol Neuroinflamm 2014;1; DOI 10.1212/NXI.0000000000000050

This information is current as of December 11, 2014






\section{Updated Information \& Services}

References

Citations

Subspecialty Collections

Permissions \& Licensing

Reprints including high resolution figures, can be found at: http://nn.neurology.org/content/1/4/e50.full.html

This article cites 7 articles, 1 of which you can access for free at: http://nn.neurology.org/content/1/4/e50.full.html\#\#ref-list-1

This article has been cited by 2 HighWire-hosted articles: http://nn.neurology.org/content/1/4/e50.full.html\#\#otherarticles

This article, along with others on similar topics, appears in the following collection(s):

All Clinical Neurology

http://nn.neurology.org//cgi/collection/all_clinical_neurology Decision analysis

http://nn.neurology.org//cgi/collection/decision_analysis

Guillain-Barre syndrome

http://nn.neurology.org//cgi/collection/guillainbarre_syndrome

Hematologic

http://nn.neurology.org//cgi/collection/hematologic

Peripheral neuropathy

http://nn.neurology.org//cgi/collection/peripheral_neuropathy

Information about reproducing this article in parts (figures,tables) or in its entirety can be found online at:

http://nn.neurology.org/misc/about.xhtml\#permissions

Information about ordering reprints can be found online:

http://nn.neurology.org/misc/addir.xhtml\#reprintsus

Neurol Neuroimmunol Neuroinflamm is an official journal of the American Academy of Neurology.

Published since April 2014, it is an open-access, online-only, continuous publication journal. Copyright $\odot$ 2014 American Academy of Neurology. All rights reserved. Online ISSN: 2332-7812.

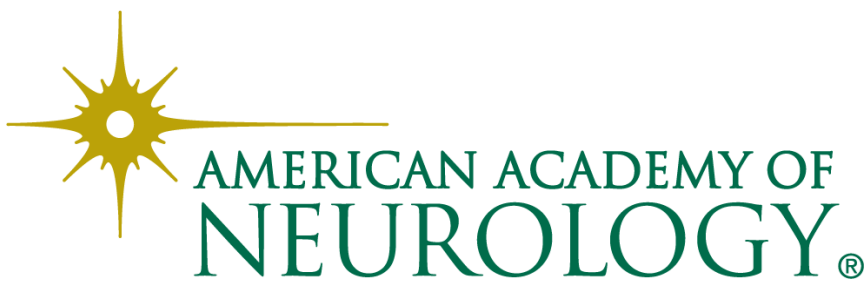

